\title{
BMJ Open Consumption of energy drinks by children and young people: a rapid review examining evidence of physical effects and consumer attitudes
}

\author{
Shelina Visram, ${ }^{1,2}$ Mandy Cheetham, ${ }^{2,3}$ Deborah M Riby, ${ }^{4}$ Stephen J Crossley, ${ }^{1}$ \\ Amelia A Lake ${ }^{1,2}$
}

To cite: Visram $S$, Cheetham M, Riby DM, et al. Consumption of energy drinks by children and young people: a rapid review examining evidence of physical effects and consumer attitudes. BMJ Open 2016;6:e010380. doi:10.1136/bmjopen-2015010380

- Prepublication history for this paper is available online. To view these files please visit the journal online (http://dx.doi.org/10.1136/ bmjopen-2015-010380).

Received 27 October 2015 Revised 29 July 2016 Accepted 2 September 2016

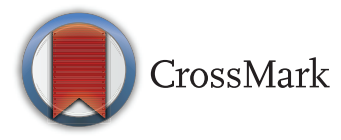

For numbered affiliations see end of article.

Correspondence to Dr Shelina Visram; shelina. visram@durham.ac.uk

\section{ABSTRACT}

Objective: To examine patterns of energy drink consumption by children and young people, attitudes towards these drinks, and any associations with health or other outcomes.

Design: Rapid evidence assessment and narrative synthesis.

Data sources: 9 electronic bibliographic databases, reference lists of relevant studies and searches of the internet.

Results: A total of 410 studies were located, with 46 meeting the inclusion criteria. The majority employed a cross-sectional design, involved participants aged 11-18 years, and were conducted in North America or Europe. Consumption of energy drinks by children and young people was found to be patterned by gender, with boys consuming more than girls, and also by activity levels, with the highest consumption observed in the most and least sedentary individuals. Several studies identified a strong, positive association between the use of energy drinks and higher odds of health-damaging behaviours, as well as physical health symptoms such as headaches, stomach aches, hyperactivity and insomnia. There was some evidence of a dose-response effect. 2 experimental studies involving small numbers of junior athletes demonstrated a positive impact on limited aspects of sports performance. 3 themes emerged from the qualitative studies: reasons for use; influences on use; and perceived efficacy and impact. Taste and energyseeking were identified as key drivers, and branding and marketing were highlighted as major influences on young people's consumption choices. Awareness of possible negative effects was low.

Conclusions: There is growing evidence that consumption of energy drinks is associated with a range of adverse outcomes and risk behaviours in terms of children's health and well-being. However, taste, brand loyalty and perceived positive effects combine to ensure their popularity with young consumers. More research is needed to explore the short-term and long-term impacts in all spheres, including health, behaviour and education.

Trial registration number: CRD42014010192.

\section{Strengths and limitations of this study}

- This is the first independent review of the scientific literature relating solely to the consumption of energy drinks by children and young people.

- Key strengths include the comprehensiveness of the searches, the systematic study selection process and rigorous synthesis methods used.

- The inclusion of qualitative research exploring children and young people's views, alongside quantitative studies on health and other effects, helps to enhance the relevance of the findings for the design and evaluation of future policy and practice interventions.

- The strength of the conclusions is limited by the quality of the individual studies, which varied due to factors such as the sample sizes, crosssectional designs and reliance on self-report data.

- Few studies examined educational or social outcomes, highlighting a need for further research that examines the short-term and long-term impact of energy drinks in relation to a wider range of outcomes.

\section{INTRODUCTION}

Energy drinks are non-alcoholic beverages that typically contain high levels of caffeine $(>150 \mathrm{mg} / \mathrm{L})$ and sugar in combination with other ingredients known to have stimulant properties. They are marketed explicitly as a way to relieve fatigue and improve mental alertness, in contrast with sports or isotonic drinks which are intended to help athletes rehydrate after exercise. There are implicit claims that energy drinks promote a more active and healthy lifestyle, in spite of the British Soft Drinks Association (BSDA) pledging that they "will not be marketed as sports beverages which deliver a rehydration benefit'. ${ }^{1}$ Between 2006 and 2014, consumption of energy drinks in the UK increased by $155 \%$, from 235 to 600 million $\mathrm{L}^{2}$ 
This equated to a per capita consumption of $9.4 \mathrm{~L}$ and a total value of $£ 1.48$ billion. Despite the growing energy drinks market and media reports of serious adverse events associated with their consumption, research into their use and effects has been sparse. In 2011, the European Food Safety Authority (EFSA) commissioned a study to gather consumption data for energy drinks in 16 countries of the European Union. ${ }^{3}$ They found that young people aged 10-18 years had the highest reported consumption prevalence (68\%), compared with adults over 18 years $(30 \%)$ and children under 10 years $(18 \%)$. On average, young people in the UK were found to consume more energy drinks than their counterparts in other EU countries $(3.1 \mathrm{~L} /$ month in comparison with $2.1 \mathrm{~L}$ ).

The scientific literature focuses largely on the effects of energy drink consumption in adults, who may experience temporary benefits such as increased cognitive performance, enhanced mood, more physical energy and promotion of wakefulness. ${ }^{4-7}$ However, evidence is emerging on the harmful physiological and psychological effects of these drinks, and it is possible that prolonged use may affect physical and mental wellbeing. ${ }^{8}$ With children and young people, anecdotal evidence suggests that those who regularly consume energy drinks can become dependent on them and even moderate consumption may be detrimental. ${ }^{9-11}$ Based on the known effects of caffeine, consumption of energy drinks may lead to: caffeine intoxication and withdrawal; sleep disruption and insomnia; and disruptive, hyperactive and risky behaviour. ${ }^{12-14}$ There are also likely to be longer term health implications associated with excessive sugar intake, such as dental erosion, obesity and type 2 diabetes. ${ }^{15-18}$

Based on the importance and impact of energy drink consumption outlined above, the objectives of this study were to review the existing literature in order to: (1) examine evidence of associations (if any) between children and young people's consumption of energy drinks and their health and well-being, social, behavioural or educational outcomes; (2) determine whether the magnitude and direction of these associations vary according to the quantity or frequency of energy drinks consumed and (3) explore children and young people's attitudes towards energy drinks and, in particular, what factors motivate them to consume or to abstain from consuming these drinks.

\section{METHODS}

We undertook a time-limited review of the literature following the guidance on rapid evidence assessments (REAs) ${ }^{19}$ REAs aim to be rigorous and explicit in method, but make concessions to breadth or depth by limiting particular aspects of the review process; for example, less exhaustive use of 'grey' sources and a preference for electronically available texts. Rapid or pragmatic reviews have been shown to produce similar results, more quickly and at a lower cost when compared with systematic reviews, suggesting that the approach employed here was useful and valid. ${ }^{20} 21$

\section{Search methods}

Searches of the following major bibliographic databases were undertaken: ASSIA, CINAHL, Cochrane Library, DARE, EMBASE, ERIC, MEDLINE, PsycINFO and Web of Science. We also conducted searches of OpenGrey and the internet using Google to locate grey literature. Specific search strategies were employed for each database. See box 1 for lists of the key terms used. The results of each search were exported to an independent database using EndNote 7 software. These databases were subsequently merged into a single unique database and duplicates were removed automatically.

We adopted an inclusive approach to locating original and review articles published between January 2000 and April 2016 that examined the consumption of energy drinks by children and young people aged $0-18$ years (or up to 20 years if still in secondary education). This period was chosen to reflect the time when major brands became widely available; for example, Red Bull was introduced in the USA in 1997 and Monster was created in 2002. The inclusion of studies was not restricted according to outcome type or study setting, although we excluded studies that only involved college or university students. Animal studies, articles not published in English and studies focusing on individual ingredients (eg, caffeine or taurine) rather than energy drinks as a whole were excluded. We also excluded opinion pieces, editorials and descriptive papers without empirical findings.

\section{Box 1 Search terms}

\section{List 1: topic}

'Energy drink' OR 'stimulant drink' OR 'energy shot' OR 'energy strip' OR 'energy mint'

List 2: population

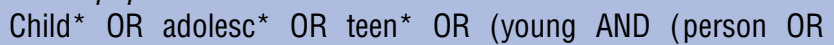
people)) OR youth

List 3: outcomes

'Health effect' $O R$ 'adverse effect' $O R$ 'positive effect' $O R$ wellbeing $O R$ 'physical energy' $O R$ wakeful ${ }^{\star} O R$ alert ${ }^{*} O R$ 'mental boost' $O R$ performance $O R$ sleep $O R$ insomnia $O R$ mood $O R$ depress* $^{*} \mathrm{R}$ anxi ${ }^{\star} \mathrm{OR}$ (caffeine AND (intoxication OR withdrawal)) $O R$ dehydrat* $O R$ headache $O R$ nausea $O R$ pain $O R$ stress OR weight OR BMI OR 'body mass index' OR 'metabolic rate' $O R$ 'blood sugar' $O R$ 'blood pressure' $O R$ 'heart rate' $O R$ cardiovascular OR (dental AND (health OR erosion OR caries)) OR ((disruptive $\mathrm{OR}$ risky OR hazardous $\mathrm{OR}$ anti-social OR criminal) AND behavio*) OR ADHD OR ADD OR 'attention hyperactivity deficit disorder' OR drug OR alcohol OR smok* OR 'screen time' OR 'physical activity' OR exercise OR sport OR sedentary OR sex $O R$ 'self-harm' $O R$ violence $O R$ injury $O R$ sociability $O R$ 'peer effects' OR learning OR memory OR attention OR attainment OR achievement OR ((absence OR exclusion) NEAR school) 


\section{Study selection}

Titles of studies identified from the searches were scanned by two researchers to make an initial assessment of relevance. In cases where there was any doubt, abstracts were retrieved in order to make a further judgement. Where possible, we obtained the full text of all references included after the title/abstract screening stage and PDF files were added to the bibliographic database. Articles deemed potentially relevant were reviewed independently by two researchers based on the inclusion criteria. Any disagreements (26 in total) were resolved by discussion between the researchers, with referral to a third member of the team where necessary. Information regarding the eligibility of a referencerelevant or not relevant-was recorded in the database to monitor the screening process. The process is summarised in the study selection flow chart (figure 1).

\section{Quality assessment}

Formal appraisal of eligible studies was undertaken using the Quality Assessment Tool for Quantitative Studies developed by the Effective Public Health Practice Project (EPHPP) and the Critical Appraisal Skills Programme checklist for qualitative studies. ${ }^{22}$ Both checklists have been widely used in previous systematic reviews and allow for rapid evaluation of study quality. Each paper was independently appraised by two researchers and disagreements (four in total) were resolved through discussion to reach an overall judgement concerning the quality of the available evidence (strong, moderate or weak). Studies rated as weak were excluded from the review. The six previous reviews located through our searches were either judged to be of insufficient quality to provide reliable evidence or they included studies involving adults or nonhuman animals, making it difficult to extract results relating specifically to children and young people. ${ }^{12} 13$ 24-27 However, they contributed to the identification of relevant primary studies.

\section{Data extraction}

Eligible studies were divided between members of the research team. Data were then extracted onto a template by the lead researcher for each study. Variables to be extracted included: bibliographic information; country of origin; study setting; methods; participant characteristics; outcomes; time frame; and results of the critical appraisal. This information was stored in a Microsoft Access database. As the object was to explore all possible health, behavioural, educational and social impacts of energy drink consumption, data were extracted on any outcomes and measures used in the studies.

\section{Data synthesis}

A quantitative synthesis proved to be inappropriate due to the heterogeneity of study designs, contexts and outcomes. Data from all studies that met the inclusion and quality criteria have therefore been descriptively summarised and narratively synthesised. Narrative synthesis relies primarily on the use of text rather than statistics to 'tell the story' of the findings from the included studies. ${ }^{28}$ This method is often used to increase the chances of the findings of a review being used in policy and practice. In the present review, the main narratives concerned the reported effects of energy drink consumption and the experiences and attitudes of young consumers, clearly related to the stated objectives.

\section{RESULTS}

\section{Study characteristics and quality}

Forty-two quantitative studies and four qualitative or mixed method studies met our inclusion criteria. The quantitative studies included 31 cross-sectional surveys, four longitudinal studies, four papers reporting retrospective analyses of national or regional poison centre data and three experimental studies (tables 1-4). Most $(n=38)$ explored the use of energy drinks by young
Figure 1 Study selection flow chart.

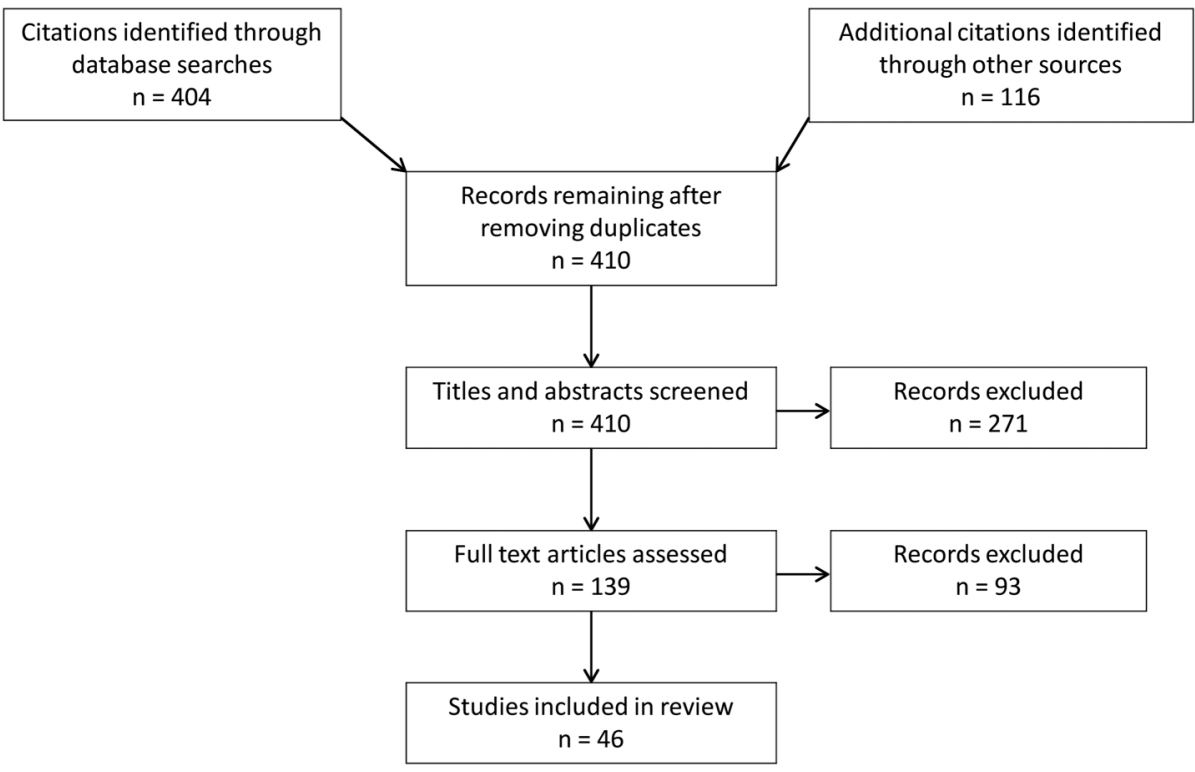


Table 1 Experimental studies

\begin{tabular}{|c|c|c|c|c|c|c|c|c|}
\hline Citation & Type & $\begin{array}{l}\text { Quality } \\
\text { assessment }\end{array}$ & Country & Participants & Study design & $\begin{array}{l}\text { Intervention and } \\
\text { dose }\end{array}$ & Outcome measures & Main findings \\
\hline $\begin{array}{l}\text { Abian-Vicen } \\
\text { et al }(2014)^{67}\end{array}$ & $\begin{array}{l}\text { Full } \\
\text { paper }\end{array}$ & Strong & Spain & $\begin{array}{l}\text { Boys }(n=16) \\
\text { Mean } 14.9 \\
\pm 0.8 \text { years }\end{array}$ & $\begin{array}{l}\text { Double-blind, } \\
\text { placebo-controlled } \\
\text { experimental design } \\
\text { with repeated measures }\end{array}$ & $\begin{array}{l}\text { A commercially } \\
\text { available ED } \\
\text { (dose: } 3 \mathrm{mg} \\
\text { caffeine } / \mathrm{kg} \text { body } \\
\text { weight) }\end{array}$ & $\begin{array}{l}\text { Jump performance, } \\
\text { power, endurance and } \\
\text { shot precision in } \\
\text { highly skilled } \\
\text { basketball players }\end{array}$ & $\begin{array}{l}\text { Significant increases in: jump } \\
\text { height, mean leg muscle } \\
\text { power output, perceived } \\
\text { muscle power, endurance } \\
\text { and vigour during the hours } \\
\text { following the test } \\
\text { Decreased rate of perceived } \\
\text { exhaustion } \\
\text { No difference in: precision of } \\
\text { basketball shots, total } \\
\text { number of free throws per } \\
\text { second or distances covered }\end{array}$ \\
\hline $\begin{array}{l}\text { Gallo-Salazar } \\
\text { et al }(2015)^{66}\end{array}$ & $\begin{array}{l}\text { Full } \\
\text { paper }\end{array}$ & Strong & Spain & $\begin{array}{l}\text { Boys and } \\
\text { girls }(n=14) \\
\text { Mean } 16 \\
\pm 1 \text { years }\end{array}$ & $\begin{array}{l}\text { Double-blind, } \\
\text { placebo-controlled } \\
\text { experimental design } \\
\text { with repeated measures }\end{array}$ & $\begin{array}{l}\text { A commercially } \\
\text { available ED } \\
\text { (dose: } 3 \mathrm{mg} \\
\text { caffeine/kg body } \\
\text { weight) }\end{array}$ & $\begin{array}{l}\text { Physical performance } \\
\text { in elite junior tennis } \\
\text { players }\end{array}$ & $\begin{array}{l}\text { Significant increases in: } \\
\text { handgrip force, running pace } \\
\text { at high intensity, and number } \\
\text { of sprints during a simulated } \\
\text { match } \\
\text { No difference in: peak } \\
\text { running speed; ball velocity } \\
\text { during the serving test } \\
\text { Sweat rate during the } \\
\text { simulated match was slightly } \\
\text { increased, producing } \\
\text { significantly higher } \\
\text { dehydration }\end{array}$ \\
\hline $\begin{array}{l}\text { Temple et al } \\
(2010)^{37}\end{array}$ & $\begin{array}{l}\text { Full } \\
\text { paper }\end{array}$ & Strong & USA & $\begin{array}{l}\text { Boys and } \\
\text { girls }(n=52) \\
12-17 \text { years }\end{array}$ & $\begin{array}{l}\text { Double blind, } \\
\text { placebo-controlled } \\
\text { experimental design }\end{array}$ & $\begin{array}{l}\text { Drinks containing } \\
0 \mathrm{mg}, 50 \mathrm{mg} \text {, } \\
100 \mathrm{mg} \text { or } 200 \mathrm{mg} \\
\text { of caffeine }\end{array}$ & $\begin{array}{l}\text { Cardiovascular and } \\
\text { subjective responses } \\
\text { to caffeine and snack } \\
\text { food ingestion }\end{array}$ & $\begin{array}{l}\text { Dose-dependent increases in } \\
\text { diastolic blood pressure } \\
\text { (DBP) and decreases in HR } \\
\text { In boys, high-caffeine } \\
\text { consumers showed greater } \\
\text { increases in DBP over time } \\
\text { than did low-consuming boys } \\
\text { High-caffeine consumers had } \\
\text { more energy, protein and fat } \\
\text { in their typical diet }\end{array}$ \\
\hline
\end{tabular}


Table 2 Retrospective studies

\begin{tabular}{|c|c|c|c|c|c|c|c|}
\hline Citation & Type & $\begin{array}{l}\text { Quality } \\
\text { assessment }\end{array}$ & Country & Participants & Study design & Outcome measures & Main findings \\
\hline $\begin{array}{l}\text { Gunja and } \\
\text { Brown } \\
(2012)^{65}\end{array}$ & Full paper & Moderate & Australia & $\begin{array}{l}\text { Boys and girls } \\
(n=62) \\
\text { All ages }\end{array}$ & $\begin{array}{l}\text { Retrospective review of } \\
\text { NSW Poisons Information } \\
\text { Centre data (January 2004- } \\
\text { December 2010) }\end{array}$ & $\begin{array}{l}\text { Calls relating to } \\
\text { caffeinated ED } \\
\text { ingestion }\end{array}$ & $\begin{array}{l}62 \text { children were reported to have accidentally } \\
\text { ingested EDs (mean age } 36 \text { months, range } \\
7-120 \text { months) } \\
14 \text { had symptoms probably related to EDs } \\
\text { (most commonly hyperactivity) and } 9 \text { required } \\
\text { hospital assessment }\end{array}$ \\
\hline $\begin{array}{l}\text { Hernandez } \\
\text { et al (2009) }\end{array}$ & $\begin{array}{l}\text { Conference } \\
\text { abstract }\end{array}$ & Moderate & USA & $\begin{array}{l}\text { Boys and girls } \\
(n=428) \\
\text { All ages }\end{array}$ & $\begin{array}{l}\text { Retrospective statistical } \\
\text { analysis of Texas regional } \\
\text { poison centres data }\end{array}$ & $\begin{array}{l}\text { Calls relating to ED } \\
\text { ingestion, negative } \\
\text { health consequences }\end{array}$ & $\begin{array}{l}\text { The largest affected group was teenagers } \\
\text { ( } n=114 \text {, compared with } 84 \text { cases }<5 \text { years) } \\
\text { Significant increases were noted between } \\
2000 \text { and } 2001(+100 \%) ; 2003-2044 \\
(+87.5 \%) \text { and } 2005-2006(+85 \%) \\
\text { Major symptoms were: rapid heart rate, } \\
\text { nervousness/agitation, nausea, vomiting, } \\
\text { upset stomach, dizziness, tremors, chest } \\
\text { discomfort and headache }\end{array}$ \\
\hline $\begin{array}{l}\text { Seifert et al } \\
(2011)^{13}\end{array}$ & Full paper & Moderate & USA & $\begin{array}{l}\text { Boys and girls } \\
(n=1568) \\
\text { All ages }\end{array}$ & $\begin{array}{l}\text { Retrospective analysis of US } \\
\text { National Poison Data } \\
\text { System }\end{array}$ & $\begin{array}{l}\text { Exposure to EDs, } \\
\text { adverse health events } \\
\text { (toxicity) }\end{array}$ & $\begin{array}{l}\text { Single product, caffeine-containing exposures } \\
\text { disproportionately involved those aged } \\
<20 \text { years (particularly males) compared with } \\
\text { other substance exposures } \\
\text { Age groups in this category were: } 47 \% \\
\text { children }<6 \text { years, } 13 \% 6-12 \text { years, } 19 \% \\
13-19 \text { years, } 12 \% 20-25 \text { years, } 9 \%>25 \text { years } \\
13-19 \text {-year-olds had the highest proportion of } \\
\text { moderate or major effects (19\%); the latter } \\
\text { included cardiac disturbances, hypertension } \\
\text { and hyperthermia }\end{array}$ \\
\hline $\begin{array}{l}\text { Seifert et al } \\
(2013)^{64}\end{array}$ & Full paper & Moderate & USA & $\begin{array}{l}\text { Boys and girls } \\
(n=4854) \\
\text { All ages }\end{array}$ & $\begin{array}{l}\text { Retrospective analysis of US } \\
\text { National Poison Data } \\
\text { System }\end{array}$ & $\begin{array}{l}\text { ED use and } \\
\text { ED-related toxicities }\end{array}$ & $\begin{array}{l}\text { Of the } 4854 \text { calls relating to ED exposure, } \\
3192 \text { cases were categorised as 'unknown', } \\
1480 \text { were non-alcoholic and } 182 \text { alcoholic } \\
\text { Children under } 6 \text { had the highest proportion of } \\
\text { unintentional exposures to non-alcoholic ED; } \\
\text { minor or moderate adverse effects were } \\
\text { reported } \\
\text { Adolescents (13-19) had the highest } \\
\text { proportions of intentional exposures and the } \\
\text { largest proportion of cases of minor to } \\
\text { moderate effects, with one major effect } \\
\text { For alcoholic ED, } 54.3 \% \text { ingestions were } \\
13-19 \text { years, } 4.1 \% 6-12 \text { years and } 9.8 \% \\
<6 \text { years; a greater proportion of alcoholic ED } \\
\text { cases were advised to seek treatment }\end{array}$ \\
\hline
\end{tabular}




\begin{tabular}{|c|c|c|c|c|c|c|c|}
\hline Citation & Type & $\begin{array}{l}\text { Quality } \\
\text { assessment }\end{array}$ & Country & Participants & Study design & Outcome measures & Main findings \\
\hline $\begin{array}{l}\text { Al-Hazzaa et al } \\
(2014)^{62}\end{array}$ & Full paper & Moderate & $\begin{array}{l}\text { Saudi } \\
\text { Arabia }\end{array}$ & $\begin{array}{l}\text { Boys and girls } \\
(n=2908) \\
15-19 \text { years }\end{array}$ & $\begin{array}{l}\text { Multicentre cross-sectional } \\
\text { study }\end{array}$ & $\begin{array}{l}\text { Weight, height, BMI, total daily } \\
\text { screen time (ST), physical } \\
\text { activity (PA) and dietary habits } \\
\text { (DH) using self-report } \\
\text { questionnaires }\end{array}$ & $\begin{array}{l}\text { Significant associations of higher } \\
\text { consumption of EDs with higher PA } \\
\text { levels and higher ST } \\
\text { PA did not correlate with } \\
\text { consumption of sugar-sweetened } \\
\text { drinks overall but did associate } \\
\text { significantly with intake of EDs } \\
\text { Insignificant associations between } \\
\text { PA and intake of EDs in females }\end{array}$ \\
\hline Arria et al $(2014)^{51}$ & Full paper & Moderate & USA & $\begin{array}{l}\text { Boys and girls } \\
(n=12267 \text { at } \\
\text { T1, } n=12381 \text { at } \\
\text { T2) } \\
13-14,15-16 \\
\text { and } 17-18 \\
\text { years }\end{array}$ & $\begin{array}{l}\text { Analysis of data from the } \\
2010 \text { and } 2011 \text { Monitoring } \\
\text { the Future (school-based) } \\
\text { Survey }\end{array}$ & $\begin{array}{l}\text { Use of EDs and energy shots, } \\
\text { sociodemographic variables }\end{array}$ & $\begin{array}{l}\text { Younger students, males and } \\
\text { Hispanic individuals were more likely } \\
\text { to drink EDs. Consumption of energy } \\
\text { shots was less prevalent than for } \\
\text { EDs and ethnic variations were less } \\
\text { apparent, although the gender } \\
\text { differences were similar. Between } \\
8 \% \text { and } 12 \% \text { of students consumed } \\
\text { EDs and energy shots. Results were } \\
\text { largely consistent between } 2010 \text { and } \\
2011\end{array}$ \\
\hline $\begin{array}{l}\text { Azagba et al } \\
(2013)^{48}\end{array}$ & Full paper & Strong & Canada & $\begin{array}{l}\text { Boys and girls } \\
(n=36155) \\
12-18 \text { years }\end{array}$ & $\begin{array}{l}\text { Cross-sectional, } \\
\text { classroom-based, biennial } \\
\text { Youth Smoking Survey }\end{array}$ & $\begin{array}{l}\text { Consumption, mixed or premixed } \\
\text { with alcohol during the past } \\
12 \text { months }\end{array}$ & $\begin{array}{l}\text { About } 20 \% \text { reported using alcohol } \\
\text { mixed with EDs in the last year; } \\
\text { prevalence } \\
\text { of use was highest among Aboriginal } \\
\text { ( } 33.8 \% \text { ) and black (25\%) students } \\
\text { Students who were older; currently } \\
\text { smoked; were involved in heavy } \\
\text { drinking in the past year; used } \\
\text { marijuana in the past year; were } \\
\text { absent from school; participated in } \\
\text { school team sports; and had } \$ 40 \text { or } \\
\text { more weekly spending money were } \\
\text { more likely to consume alcohol } \\
\text { mixed with EDs in the previous year } \\
\text { Students who felt more connected to } \\
\text { school and who had an academic } \\
\text { average of } 70 \% \text { or higher were less } \\
\text { likely to consume EDs }\end{array}$ \\
\hline $\begin{array}{l}\text { Azagba and Sharaf } \\
(2014)^{55}\end{array}$ & Full paper & Strong & Canada & $\begin{array}{l}\text { Boys and girls } \\
(n=15875) \\
14-18 \text { years }\end{array}$ & $\begin{array}{l}\text { Cross-sectional, } \\
\text { classroom-based, biennial } \\
\text { Youth Smoking Survey }\end{array}$ & $\begin{array}{l}\text { Susceptibility to smoking, } \\
\text { consumption of alcohol mixed } \\
\text { with ED (AmED) }\end{array}$ & $\begin{array}{l}\text { About } 13 \% \text { of students used AmED } \\
\text { A statistically significant positive } \\
\text { association was identified between } \\
\text { consuming AmED and susceptibility } \\
\text { to smoking among adolescent } \\
\text { students }\end{array}$ \\
\hline
\end{tabular}


Table 3 Continued

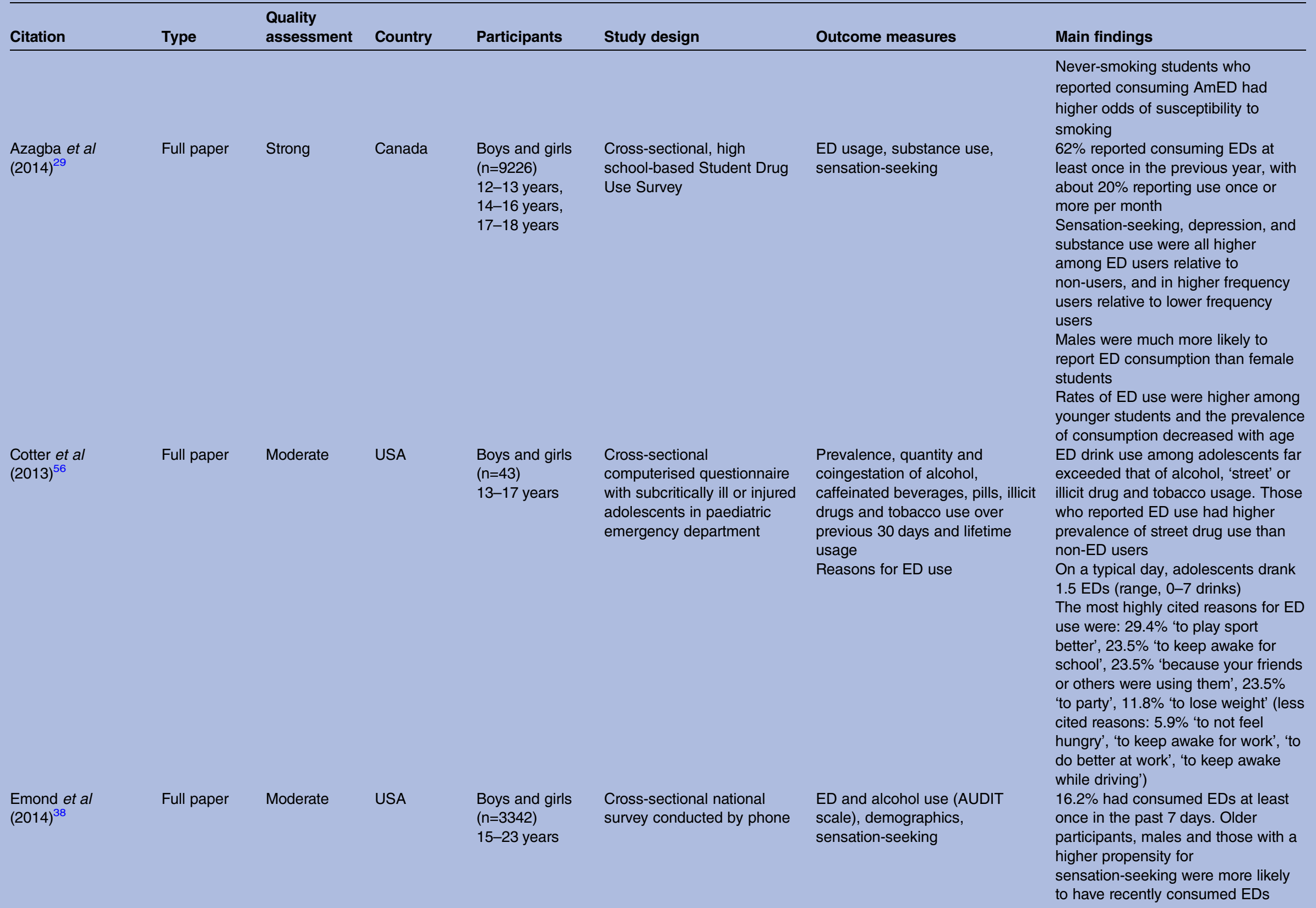

Continued 


\begin{tabular}{|c|c|c|c|c|c|c|c|}
\hline $\begin{array}{l}\text { Evren and Evren } \\
(2015)^{39}\end{array}$ & Full paper & Strong & Turkey & $\begin{array}{l}\text { Boys and girls } \\
(n=4957) \\
15-16 \text { years } \\
\text { (mean } \\
15.6 \text { years) }\end{array}$ & $\begin{array}{l}\text { Cross-sectional, } \\
\text { classroom-based online } \\
\text { survey }\end{array}$ & $\begin{array}{l}\text { Demographics, school life and } \\
\text { performance, psychological } \\
\text { trauma, psychological and } \\
\text { behavioural problems, substance } \\
\text { use }\end{array}$ & $\begin{array}{l}\text { ED consumption was associated } \\
\text { with being male, lifetime substance } \\
\text { use, sensation-seeking, } \\
\text { psychological problems and } \\
\text { self-destructive behaviour. In most } \\
\text { cases, there was evidence of a } \\
\text { dose-response effect } \\
\text { There was no significant association } \\
\text { between ED use and age }\end{array}$ \\
\hline Faris et al (2015) ${ }^{49}$ & Full paper & Moderate & $\begin{array}{l}\text { Saudi } \\
\text { Arabia }\end{array}$ & $\begin{array}{l}\text { Boys only } \\
(n=1006) \\
12-18 \text { years }\end{array}$ & $\begin{array}{l}\text { Cross-sectional, } \\
\text { school-based, multiple } \\
\text { choice, validated } \\
\text { questionnaire }\end{array}$ & $\begin{array}{l}\text { ED use, nutritional and lifestyle } \\
\text { factors }\end{array}$ & $\begin{array}{l}60.2 \% \text { consumed EDs. Frequency } \\
\text { and quantity of consumption were } \\
\text { both significantly higher in secondary } \\
\text { school students than middle school } \\
\text { students. Higher disposable income } \\
\text { and poor lifestyle behaviours } \\
\text { (irregular sleep, smoking, drinking } \\
\text { alcohol, low physical activity and } \\
\text { unsafe behaviours such as not } \\
\text { wearing a seatbelt while driving) } \\
\text { were also associated with ED } \\
\text { consumption } \\
\text { Poor knowledge concerning ED } \\
\text { composition was reported. } \\
\text { Physiological effects reported by } \\
\text { consumers were reduced sleeping } \\
\text { hours (23.6\%), changes in cardiac } \\
\text { activity (18.9\%) and becoming } \\
\text { energised/activated (16.6\%) }\end{array}$ \\
\hline $\begin{array}{l}\text { Gallimberti et al } \\
(2013)^{47}\end{array}$ & Full paper & Moderate & Italy & $\begin{array}{l}\text { Boys and girls } \\
(n=913) \\
11-13 \text { years }\end{array}$ & $\begin{array}{l}\text { Cross-sectional } \\
\text { school-based survey }\end{array}$ & $\begin{array}{l}\text { Consumption of EDs, other } \\
\text { substance abuse }\end{array}$ & $\begin{array}{l}\text { Use of EDs increased significantly } \\
\text { with age, from } 17.8 \% \text { among sixth } \\
\text { graders to } 56.2 \% \text { among eighth } \\
\text { graders } \\
\text { Among the male student population, } \\
16.5 \% \text { of those in the eighth grade } \\
\text { and } 6.21 \% \text { of those in the sixth grade } \\
\text { drank them at least once a week }\end{array}$ \\
\hline
\end{tabular}


Outcome measures

Cross-sectional, Boys and girls $(n=1496)$ 10-16 years 76 classes

$\begin{array}{lll}\text { Gambon et al } & \text { Full paper } \quad \text { Moderate } & \begin{array}{l}\text { The } \\ \text { Netherlands }\end{array}\end{array}$

Netherlands

Boys and girls $(\mathrm{n}=502)$ 12-19 years
Cross-sectional school-based survey, single centre
Data on consumption of EDs, soft drinks, sports drinks and alcopops
Alcohol and substance use and abuse
Hamilton et

$(2013)^{57}$

$\begin{array}{lll}\text { Full paper Strong } & \text { Canada } & \text { Boys and girls } \\ & & (\mathrm{n}=4472) \\ & 12-19 \text { years }\end{array}$

Retrospective review of Ontario Student Drug Use and Health Survey
ED intake

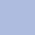

\section{Main findings}

Independent variables conferring a higher likelihood of being at least once-a-week ED consumers were smoking and alcohol consumption. Awareness of the damage caused by EDs emerged as a protective factor that reduced the likelihood of young students consuming such drinks Smoking, alcohol and ED use increased with age. ED use was more common in males, with the exception of those in the fifth grade. Lifetime ED consumption in the eighth grade was $64.0 \%$ and $36.4 \%$ for males and females, respectively $39.4 \%$ used EDs (in comparison with $85.2 \%$ soft drinks, $44.7 \%$ sports drinks, $12.8 \%$ alcopops)

Boys consumed soft drinks, EDs and sports drinks more frequently than girls, and on average also consumed higher amounts of these drinks

Significant positive associations were observed between the consumption of soft drinks, EDs and/or sports drinks. Alcopop consumption was only associated with EDs

The mean consumption of soft drinks, EDs and sports drinks was highest at 14-15 years, after which it declined

$49.6 \%$ of adolescents had consumed EDs in the previous year

Energy drink consumption in the previous year was highly associated with tobacco, cannabis and non-medicinal use of prescription drugs use in the previous year, and binge drinking in the previous month. Consumption was also highly associated with sensation-seeking and self-reports of medical treatment for an injury (reported by $16 \%$ and $42 \%$ of adolescents) 


\begin{tabular}{llllll} 
Citation & Type & $\begin{array}{l}\text { Quality } \\
\text { assessment }\end{array}$ & Country & Participants & Study design \\
\hline $\begin{array}{l}\text { Huhtinen et al } \\
(2013)^{31}\end{array}$ & $\begin{array}{l}\text { Conference } \\
\text { abstract }\end{array}$ & Moderate & Finland & $\begin{array}{l}\text { Boys and girls } \\
(n=10406)\end{array}$ & $\begin{array}{l}\text { Adolescent Health and } \\
\text { Lifestyle Survey, postal and } \\
\text { online survey }\end{array}$
\end{tabular}

Outcome measures

Association between EDs and four caffeine-induced health symptoms (headache, sleeping problems, irritation, tiredness/ fatigue)

Traumatic brain injuries (TBIs),

Population-based

Boys and girls $(\mathrm{n}=10272)$ 11-20 years school survey (Ontario Student Drug Use and Health Survey)

$\begin{array}{lllll}\begin{array}{l}\text { Koivusilta } \text { et al } \\ (2016)^{63}\end{array} & \text { Full paper } \quad \text { Moderate } & \text { Finland } & \begin{array}{l}\text { Boys and girls } \\ (n=9446) \\ 13 \text { years }\end{array} & \begin{array}{l}\text { Cross-sectional, classroom } \\ \text { based survey }\end{array} \\ & & & \end{array}$
$(2014)^{4}$

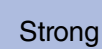

Strong
Iceland Boys and girls $(\mathrm{n}=11267)$ 10-12 years
Population-based primary school survey
ED and alcohol use

Frequency of ED consumption, health symptoms, time of going to bed on school days

Prevalence of caffeinated sugar-sweetened beverages (CSSBs) and the relationship with common physical symptoms

\section{Main findings}

$44 \%$ of adolescents used EDs at least sometimes ( $2 \%$ of girls and $4 \%$ of boys used them daily, $0.5 \%$ several times a day)

Daily use of EDs was strongly associated with the four health symptoms. In adjusted models, health symptoms among those who used EDs several times a day were multifold compared with the non-users: headache $(\mathrm{OR}=4.5)$, sleeping problems (3.5), irritation (2.4) and tiredness/fatigue (3.4).

Gender, alcohol use, ED consumption, AmED and academic performance were identified as significant predictors of TMI. The odds of sustaining a lifetime or recent TBI increased with consumption of alcohol and EDs The percentage of adolescents suffering from health symptoms (headache, irritation or outburst of anger, trouble falling asleep or waking at night, tiredness/fatigue) or going to bed late increased with

increasing frequency of ED consumption. The relationship between EDs and health symptoms was partly mediated through going to bed late. Results were similar for both genders Just over $7 \%$ of boys and almost $3 \%$ of girls

reported consuming EDs on a daily basis

Use of CSSBs was more common among boys and physical symptoms were more common among girls. About one in five girls reported having headaches, stomach aches and/or sleeping problems sometimes or often during previous 7 days. The prevalence of physical symptoms generally increased for both genders with greater ED use 


\begin{tabular}{lllllll}
\hline Citation & Type & $\begin{array}{l}\text { Quality } \\
\text { assessment }\end{array}$ & Country & Participants & Study design & Outcome measures \\
\hline $\begin{array}{l}\text { Kumar et al } \\
(2014)^{32}\end{array}$ & Full paper & Strong & USA & $\begin{array}{l}\text { Boys and girls } \\
(n=840) \\
12-17 \text { years }\end{array}$ & Online survey & ED consumption
\end{tabular}

\begin{tabular}{|c|c|c|c|c|c|}
\hline $\begin{array}{l}\text { Larson et al } \\
(2014)^{33}\end{array}$ & Full paper & Strong & USA & $\begin{array}{l}\text { Boys and girls } \\
(n=2793) \\
\text { Mean } \\
14.4 \text { years (SD } \\
2.0 \text { years) }\end{array}$ & $\begin{array}{l}\text { Cross-sectional } \\
\text { school-based survey } \\
\text { (questionnaire plus } \\
\text { anthropometric measures) }\end{array}$ \\
\hline
\end{tabular}

Sport and ED intake, PA and sport participation, media use, sleep, cigarette smoking,

breakfast frequency and other beverage intake, weight status, demographics

Alcohol use by socioeconomic level and gender

\section{Main finding}

$9 \%$ reported consuming ED $\geq 1$ time/ week

Significant differences were found by age and gender (increasing

prevalence among older teens and

in males) but not for the other

characteristics examined

Only $11.5 \%$ were ever asked by their doctor/nurse about how often they drank EDs, and $11.1 \%$ were ever recommended by their doctor/nurse to not drink EDs

The proportion of youth who consumed energy drinks $\geq 1$ time/ week was higher among youth who were asked by their doctor/nurse about how often they drank energy drinks than by youth who were not

Overall, EDs were consumed at least $1 /$ wk by $14.7 \%$ of the sample

(significantly higher among boys than girls). Differences in ED consumption by ethnicity were statistically significant only among girls

Regular ED consumption was associated with measures of media use, other beverage intake and cigarette use, but was unrelated to measures of PA. For both genders, regular consumption was positively associated with ever having smoked cigarettes and weekly video game use

There was a significant association between regular ED consumption and higher daily intake of sugar-sweetened soft drinks and fruit drinks. For girls only, there was also a significant association with lower frequency of breakfast

$31.6 \%$ reported having used alcohol and ED together at least once in life. Boys reported a higher prevalence of frequent alcohol use, binge drinking and the combination of alcohol with ED 


\begin{tabular}{|c|c|c|c|c|c|c|}
\hline Citation & Type & $\begin{array}{l}\text { Quality } \\
\text { assessment }\end{array}$ & Country & Participants & Study design & Outcome measures \\
\hline
\end{tabular}

\begin{tabular}{|c|c|c|c|c|c|c|c|}
\hline $\begin{array}{l}\text { Lubman et al } \\
(2014)^{59}\end{array}$ & Full paper & Moderate & Australia & $\begin{array}{l}\text { Boys and girls } \\
(n=558) \\
17-18 \text { years }\end{array}$ & $\begin{array}{l}\text { Breathalyser tests and brief } \\
\text { 'on street' surveys }\end{array}$ & $\begin{array}{l}\text { Alcohol, ED and illicit drug use, } \\
\text { experience of aggressive } \\
\text { incidents, alcohol-related injury } \\
\text { and unprotected sex }\end{array}$ & $\begin{array}{l}\text { in classes D/E (high to low) } \\
\text { Those who coconsumed alcohol and } \\
\text { energy drinks (one in six } \\
\text { participants) recorded a significantly } \\
\text { higher blood alcohol content ( } 11.34 \\
\text { vs } 8.30 \text { ), reported feeling more } \\
\text { intoxicated and were rated as more } \\
\text { intoxicated by interviewers than } \\
\text { alcohol-only users }\end{array}$ \\
\hline $\begin{array}{l}\text { Bryant Ludden and } \\
\text { Wolfson }(2010)^{36}\end{array}$ & Full paper & Moderate & USA & $\begin{array}{l}\text { Boys and girls } \\
(n=197) \\
14-18 \text { years }\end{array}$ & $\begin{array}{l}\text { Self-report measures } \\
\text { completed during school } \\
\text { hours }\end{array}$ & $\begin{array}{l}\text { Patterns of caffeine use, linking } \\
\text { to reasons for use, expectancies } \\
\text { and sleep patterns }\end{array}$ & $\begin{array}{l}\text { Among those who used caffeine the } \\
\text { previous day, } 6.1 \% \text { reported ED use } \\
\text { (compared with } 60.5 \% \text { soda, } 19.3 \% \\
\text { coffee, } 4.4 \% \text { tea and } 8.8 \% \text { other) } \\
\text { Males drank soda and ED more } \\
\text { frequently, although females were } \\
\text { more likely to report withdrawal/ } \\
\text { dependence caffeine expectancies } \\
\text { and appetite suppression } \\
\text { expectancies }\end{array}$ \\
\hline $\begin{array}{l}\text { Magnezi et al } \\
(2015)^{50}\end{array}$ & Full paper & Moderate & Israel & $\begin{array}{l}\text { Boys and girls } \\
(n=802) \\
14-18 \text { years }\end{array}$ & School-based survey & $\begin{array}{l}\text { ED and alcohol mixed with ED } \\
\text { (AmED) consumption }\end{array}$ & $\begin{array}{l}84.2 \% \text { had ever drunk EDs. } \\
\text { Consumption was more common } \\
\text { among older students, immigrants, } \\
\text { those from single parent families, } \\
\text { and boys, who were more likely than } \\
\text { girls to drink them daily. Those who } \\
\text { began drinking at an earlier age were } \\
\text { more likely to consume AmED } \\
50.2 \% \text { drank EDs because of the } \\
\text { taste, } 12.7 \% \text { to feel energised, } \\
19.3 \% \text { in order to mix with alcohol, } \\
11 \% \text { to stay awake and } 5.3 \% \\
\text { reported drinking out of curiosity. } \\
\text { More than half knew that EDs mask } \\
\text { the effect of alcohol and most knew } \\
\text { that those who drink AmED drink } \\
\text { more alcohol than those who do not } \\
\text { mix it with ED }\end{array}$ \\
\hline $\begin{array}{l}\text { Musaiger and } \\
\text { Zagzoog }(2014)^{35}\end{array}$ & Full paper & Moderate & $\begin{array}{l}\text { Saudi } \\
\text { Arabia }\end{array}$ & $\begin{array}{l}\text { Boys and girls } \\
(n=1061) \\
12-19 \text { years }\end{array}$ & $\begin{array}{l}\text { School-based short } \\
\text { questionnaire extracted from } \\
\text { a validated questionnaire, } \\
\text { after modifications to include } \\
\text { ED }\end{array}$ & $\begin{array}{l}\text { Knowledge, attitudes and intake } \\
\text { of energy drinks among } \\
\text { adolescents }\end{array}$ & $\begin{array}{l}31.9 \% \text { of males and } 24.7 \% \text { of } \\
\text { females drank EDs } 1-2 \text { days/week, } \\
\text { with a significant difference between } \\
\text { the genders }\end{array}$ \\
\hline
\end{tabular}


Table 3 Continued

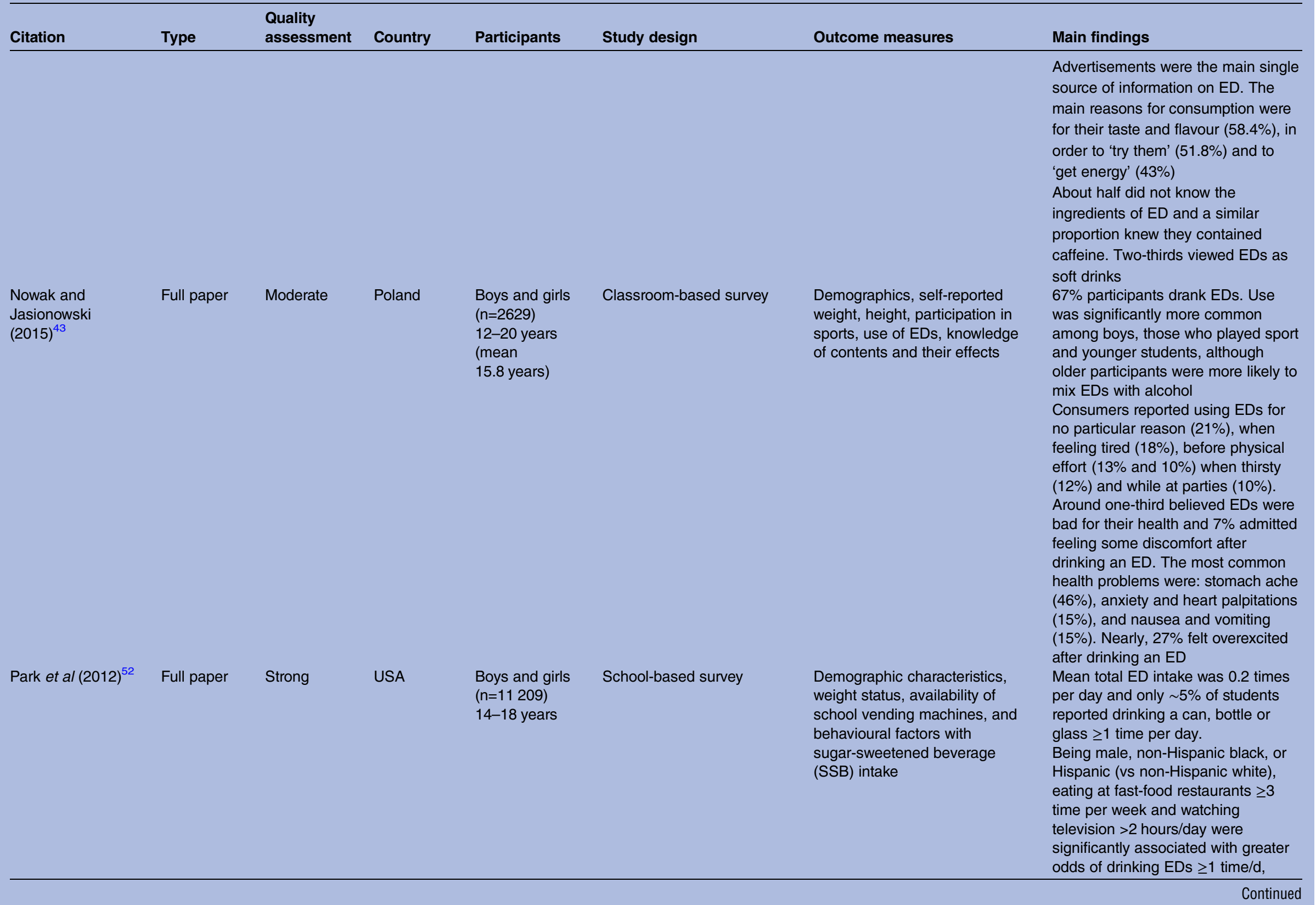




Citation

Reid et al (2015) ${ }^{44}$

Full paper

Canada

Boys and girls $(\mathrm{n}=23610)$

14-18 years retrospective cohort study (COMPASS) involving a school-based survey

Schwartz et al

Full paper

Strong

USA
Boys and girls
$(\mathrm{n}=1649)$

$10-11,12-13$

14 years (mean

12.4 years)
30 min online, classroom based health survey
Hyperactivity/Inattention subscale of the Strengths and Difficulties questionnaire, number and types of sweetened beverages

ED consumption and substance

Boys and girls
Classroom based

self-completion

questionnaire
ED and alcohol use, sociodemographic variables

$$
(2014)^{14}
$$ $(\mathrm{n}=21$ 995) 13-18 years

Main findings

whereas having beverage vending machines in the school was significantly associated with reduced odds of drinking EDs $\geq 1$ time/day The odds of using EDs were significantly greater in the following groups: males, off-reserve Aboriginal students, and students reporting some spending money. Among males, ED use increased with age, while the opposite was true for females. Students with a healthy BMI were less likely to report consuming EDs than those who were underweight or obese

Intensity of alcohol use was strongly associated with ED use. Binge drinking was the strongest predictor of using alcohol mixed with EDs

Boys reported drinking significantly more EDs. Black and Hispanic students were more likely to report consumption of EDs.

Students who reported consuming EDs were $66 \%$ more likely to score in the at-risk category on the hyperactivity/inattention subscale compared with students who did not, regardless of overall sweetened beverage intake.

For each additional sweetened beverage, the odds of being at risk for hyperactivity/inattention increased by $14 \%$. After adding beverage types to the model, only EDs had an independent association with risk of hyperactivity/inattention, even after adjusting for number of drinks consumed and other potential confounders.

ED/shot use was higher among boys, younger students and those residing outside of metropolitan areas. There were negative 


\begin{tabular}{|c|c|c|c|c|c|c|c|}
\hline Citation & Type & $\begin{array}{l}\text { Quality } \\
\text { assessment }\end{array}$ & Country & Participants & Study design & Outcome measures & Main findings \\
\hline & & & & & & & $\begin{array}{l}\text { relationships with two parents in the } \\
\text { home and higher average parental } \\
\text { education. Neither race/ethnicity nor } \\
\text { region was associated with ED/shot } \\
\text { use and consumption did not } \\
\text { significantly change between } 2010 \\
\text { and } 2011 \\
\text { ED/shot use frequency was } \\
\text { significantly and positively correlated } \\
\text { with past } 30-\text { day use frequency of all } \\
\text { substance use measures (alcohol, } \\
\text { cigarettes, marijuana and } \\
\text { amphetamines) for all grades }\end{array}$ \\
\hline $\begin{array}{l}\text { Van } \\
\text { Batenburg-Eddes } \\
\text { et al }(2014)^{61}\end{array}$ & Full paper & Strong & $\begin{array}{l}\text { The } \\
\text { Netherlands }\end{array}$ & $\begin{array}{l}\text { Boys and girls } \\
(n=509) \\
11-16 \text { years } \\
\text { (mean } \\
13.1 \text { years, SD } \\
0.85)\end{array}$ & $\begin{array}{l}\text { Cross-sectional } \\
\text { school-based survey, part of } \\
\text { a larger longitudinal project }\end{array}$ & $\begin{array}{l}\text { Executive functions, plus } \\
\text { caffeine and ED intake }\end{array}$ & $\begin{array}{l}6 \% \text { reported consuming on average } \\
\text { at least one ED a day. Problems with } \\
\text { falling asleep and waking up were } \\
\text { reported most often (23\%). } \\
\text { Consuming on average one ED or } \\
\text { more a day was associated with } \\
\text { problems with self-reported } \\
\text { behaviour regulation. Participants } \\
\text { who drank at least two consumptions } \\
\text { of caffeine or ED also had more } \\
\text { problems with metacognitive skills }\end{array}$ \\
\hline $\begin{array}{l}\text { Vilija and } \\
\text { Romualdas } \\
(2014)^{54}\end{array}$ & Full paper & Strong & Lithuania & $\begin{array}{l}\text { Boys and girls } \\
(n=1747) \\
12-13 \text { years }\end{array}$ & $\begin{array}{l}\text { Cross-sectional } \\
\text { school-based study using } \\
\text { self- administered } \\
\text { questionnaire }\end{array}$ & $\begin{array}{l}\text { Post-traumatic stress (PTS) } \\
\text { symptoms, lifetime traumatic } \\
\text { experiences, food frequency } \\
\text { scale, sense of coherence scale }\end{array}$ & $\begin{array}{l}21.0 \% \text { consumed EDs on a daily } \\
\text { basis. All lifetime traumatic events } \\
\text { were associated with unhealthy } \\
\text { foods (including EDs) and sense of } \\
\text { coherence weakened the strength of } \\
\text { the associations }\end{array}$ \\
\hline
\end{tabular}




\begin{tabular}{|c|c|c|c|c|c|c|c|}
\hline Citation & Type & $\begin{array}{l}\text { Quality } \\
\text { assessment }\end{array}$ & Country & Participants & Study design & Outcome measures & Main findings \\
\hline $\begin{array}{l}\text { Choi et al } \\
(2016)^{58}\end{array}$ & $\begin{array}{l}\text { Short } \\
\text { paper }\end{array}$ & Moderate & USA & $\begin{array}{l}\text { Boys and girls } \\
(n=894 \text { at } T 1, \\
n=780 \text { at } T 2) \\
16-18 \text { years } \\
\text { (mean } \\
17.0 \text { years, SD } \\
0.77 \text { ) }\end{array}$ & $\begin{array}{l}\text { Longitudinal mixed mode } \\
\text { survey (web, telephone and } \\
\text { paper) at baseline and } \\
12 \text { months }\end{array}$ & $\begin{array}{l}\text { Alcohol and ED use, binge } \\
\text { drinking }\end{array}$ & $\begin{array}{l}\text { ED use was positively associated } \\
\text { with alcohol use. After controlling } \\
\text { for alcohol use at baseline, the } \\
\text { effect size of ED use in the past } \\
\text { month decreased or became } \\
\text { non-significant. ED use at baseline } \\
\text { predicted the number of drinking } \\
\text { days, but not past month binge } \\
\text { drinking or average drinks per } \\
\text { drinking day, at follow-up }\end{array}$ \\
\hline $\begin{array}{l}\text { Martz et al } \\
(2015)^{60}\end{array}$ & $\begin{array}{l}\text { Full } \\
\text { paper }\end{array}$ & Moderate & USA & $\begin{array}{l}\text { Boys and girls } \\
(n=6498) \\
17-18 \text { years }\end{array}$ & $\begin{array}{l}\text { Monitoring the Futures } \\
\text { surveys completed by } 12 \text { th } \\
\text { grade students in } 2012 \text { and } \\
2013\end{array}$ & $\begin{array}{l}\text { Use of alcohol mixed with } \\
\text { EDs (AmED), academic and } \\
\text { social factors, other } \\
\text { substance use, unsafe } \\
\text { driving }\end{array}$ & $\begin{array}{l}\text { Males had significantly greater } \\
\text { odds of any AmED use than } \\
\text { females, and White or Hispanic } \\
\text { students had significantly greater } \\
\text { odds than Black students. AmED } \\
\text { use was significantly associated } \\
\text { with greater odds of driving } \\
\text { violations and accidents after } \\
\text { alcohol use, controlling for all other } \\
\text { variables }\end{array}$ \\
\hline $\begin{array}{l}\text { Miyake and } \\
\text { Marmorstein } \\
(2015)^{53}\end{array}$ & $\begin{array}{l}\text { Full } \\
\text { paper }\end{array}$ & Moderate & USA & $\begin{array}{l}\text { Boys and girls } \\
(n=144 \text { at T1, } \\
n=127 \text { at T2) } \\
11-13 \text { years }\end{array}$ & $\begin{array}{l}\text { Classroom-based survey at } \\
\text { baseline and } 16 \text { months }\end{array}$ & $\begin{array}{l}\text { Use of caffeinated drinks and } \\
\text { alcohol, sensation-seeking, } \\
\text { parental monitoring }\end{array}$ & $\begin{array}{l}\text { Frequency of ED consumption at } \\
\text { baseline predicted increases in } \\
\text { frequency of alcohol consumption } \\
16 \text { months later. Lower levels of } \\
\text { parental monitoring were } \\
\text { associated with higher levels of ED } \\
\text { consumption and later frequency of } \\
\text { alcohol use } \\
\text { There were significant associations } \\
\text { between baseline levels of } \\
\text { sensation-seeking and frequency of } \\
\text { ED consumption, but not later } \\
\text { alcohol use }\end{array}$ \\
\hline $\begin{array}{l}\text { Richards and } \\
\text { Smith }(2016)^{46}\end{array}$ & $\begin{array}{l}\text { Full } \\
\text { paper }\end{array}$ & Strong & UK & $\begin{array}{l}\text { Boys and girls } \\
(n=2610 \text { at } T 1, \\
n=2307 \text { at } T 2) \\
11-16 \text { years }\end{array}$ & $\begin{array}{l}\text { Longitudinal study of diet in } \\
\text { secondary school children, } \\
\text { using the Diet and Behaviour } \\
\text { Scale, at baseline and } \\
6 \text { months }\end{array}$ & $\begin{array}{l}\text { Dietary intake of common } \\
\text { foods and drinks, exercise } \\
\text { frequency, and self-assessed } \\
\text { mental health (at T2 only) }\end{array}$ & $\begin{array}{l}\text { Drinking EDs once a week or more } \\
\text { was significantly associated with } \\
\text { being male, older, having special } \\
\text { educational needs and being } \\
\text { eligible for free school meals. } \\
\text { Those who consumed EDs once a } \\
\text { week or more slept for fewer hours } \\
\text { per night, achieved lower school }\end{array}$ \\
\hline
\end{tabular}




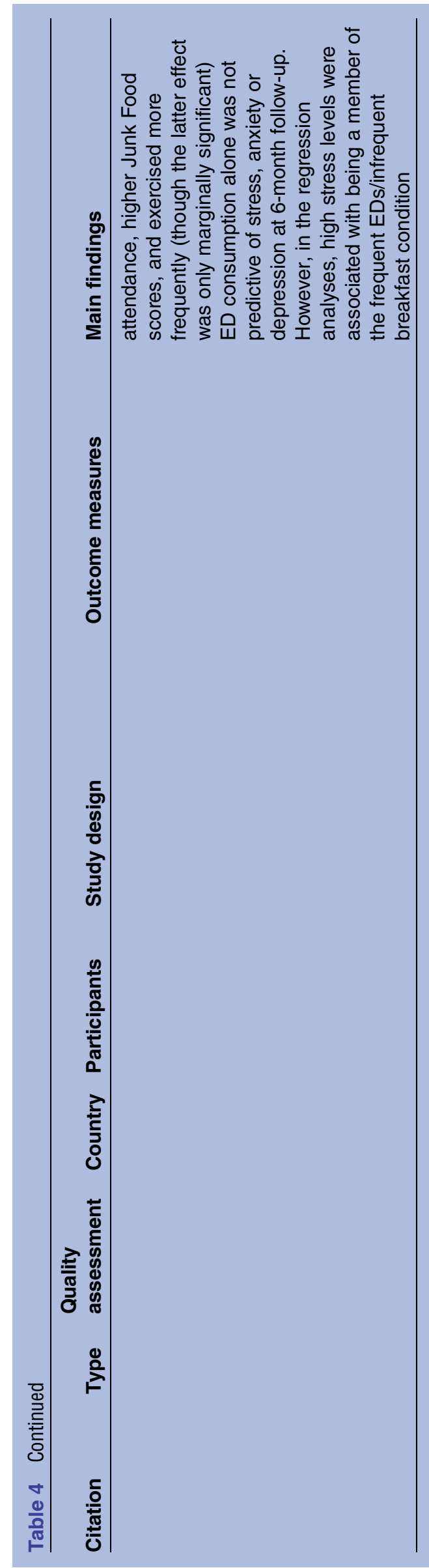

people aged between 11 and 18 years. Studies were largely conducted in North America $(\mathrm{n}=22)$ or Europe $(n=12)$, yet all of the qualitative studies were from Australia or New Zealand (table 5). Other study contexts included the Middle East $(n=5)$ and South America $(n=1)$. Equal numbers of studies were rated as being of strong or moderate quality ( $\mathrm{n}=23 \mathrm{each})$.

\section{Effects of energy drink consumption}

Consumption patterns and associations with health-related

\section{behaviours}

Cross-sectional survey data suggest that the use of energy drinks is patterned by gender, with several studies indicating that boys were more likely to report consumption than girls, and in greater quantities. ${ }^{29-46}$ Larson $e t a p^{33}$ found a significant association between regular consumption and lower frequency of breakfast for girls only, while Bryant Ludden and Wolfson ${ }^{36}$ found that girls were more likely than boys to report expectations around appetite suppression. Patterns of use according to age were less clear cut, with some studies showing that consumption levels increased with age $\mathrm{e}^{32} 384046-50$ and others demonstrating that the converse was true. ${ }^{29} 434851$ Mixed racial and ethnic patterns were also identified. Martz et al found that black students were less likely to consume energy drinks than their white or Hispanic counterparts, whereas other studies have suggested that consumption levels are highest among black, Hispanic and/or Aboriginal students. ${ }^{44}{ }^{52}$ Higher consumption levels were positively associated with being underweight or obese, being from a single parent family, receiving free school meals, having special educational needs and higher spending money. ${ }^{44} 46$ 48-50 Young people with higher academic averages, higher sense of coherence, higher levels of parental monitoring and more educated parents were less likely to consume energy drinks. ${ }^{14} 41485354$

The main health-related behaviours found to be positively and consistently associated with energy drink consumption were use of alcohol and/or binge drinking, smoking or susceptibility to smoking and other substance use. $^{14} 30333438394147$ 55-57 Recent longitudinal studies have found that the use of energy drinks at baseline predicted either number of drinking days or frequency of alcohol consumption at follow-up (12 or 16 months). ${ }^{53} 58$ Furthermore, young people who consumed alcohol mixed with energy drinks were more likely to feel and be perceived as more intoxicated, and to have greater odds of driving violations and accidents, after controlling for all other factors. ${ }^{59}{ }^{60}$ Consumption of energy drinks has been linked to sensation-seeking, ${ }^{29} 38 \quad 3953 \quad 57$ selfdestructive behaviour, ${ }^{39}$ problems with behavioural regulation and metacognitive skills, ${ }^{61}$ and poor lifestyle behaviours, ${ }^{49}$ including regularly eating junk food or fast food. ${ }^{46}$ Al-Hazzaa et a ${ }^{62}$ found that energy drink use was associated with increased sedentary behaviour and with higher levels of physical activity. This finding was reinforced by Larson $e t a l^{33}$ and Park $e t a l,{ }^{52}$ who found 
Table 5 Qualitative and mixed method studies

\begin{tabular}{|c|c|c|c|c|c|c|c|}
\hline Citation & Type & $\begin{array}{l}\text { Quality } \\
\text { assessment }\end{array}$ & Country & Participants & Study design & Aims & Main findings \\
\hline $\begin{array}{l}\text { Bunting } \\
\text { et al } \\
(2013)^{68}\end{array}$ & $\begin{array}{l}\text { Full } \\
\text { paper }\end{array}$ & Strong & $\begin{array}{l}\text { New } \\
\text { Zealand }\end{array}$ & $\begin{array}{l}\text { Boys and girls } \\
(n=12) \\
16-35 \text { years }\end{array}$ & $\begin{array}{l}\text { Focus groups stratified by } \\
\text { age (16-21, 22-28 and } \\
29-35 \text { years) }\end{array}$ & $\begin{array}{l}\text { To obtain participants' } \\
\text { perceptions of caffeinated } \\
\text { EDs }\end{array}$ & $\begin{array}{l}\text { Themes: advertising, age, alcohol, } \\
\text { brand, efficacy, energy-seeking, gender, } \\
\text { health, peer influence, product attributes, } \\
\text { and safety } \\
\text { Taste appeared to be the primary driver } \\
\text { motivating the purchase and repurchase } \\
\text { of EDs }\end{array}$ \\
\hline $\begin{array}{l}\text { Costa } \\
\text { et al } \\
(2014)^{69}\end{array}$ & $\begin{array}{l}\text { Full } \\
\text { paper }\end{array}$ & Strong & Australia & $\begin{array}{l}\text { Boys and girls } \\
(n=40) \\
12-15 \text { years }\end{array}$ & Focus groups & $\begin{array}{l}\text { To explore perceptions, } \\
\text { patterns, and contexts of ED } \\
\text { use }\end{array}$ & $\begin{array}{l}\text { Themes: knowledge about ED brands } \\
\text { and content, ED use, reasons for ED } \\
\text { use, physiological effects and influences } \\
\text { on ED use } \\
\text { Participants were familiar with a range of } \\
\text { EDs and most had used them at least } \\
\text { once, but had limited knowledge of ED } \\
\text { ingredients and could not easily } \\
\text { differentiate them from other drink types }\end{array}$ \\
\hline $\begin{array}{l}\text { Jones } \\
(2011)^{70}\end{array}$ & $\begin{array}{l}\text { Full } \\
\text { paper }\end{array}$ & Strong & Australia & $\begin{array}{l}\text { Boys and girls } \\
(n=95) \\
12-14 \text { years } \\
15-17 \text { years }\end{array}$ & $\begin{array}{l}\text { Focus groups (separate by } \\
\text { age and gender), } \\
\text { supplemented with school } \\
\text { and online survey data }\end{array}$ & $\begin{array}{l}\text { To explore perceptions and } \\
\text { consumption of alcohol EDs } \\
\text { (AEDs) }\end{array}$ & $\begin{array}{l}\text { Many participants commenting that they } \\
\text { had consumed AEDs, or seen others } \\
\text { consuming them. Findings suggest they } \\
\text { may be particularly popular among } \\
\text { young females } \\
\text { Drinking in the } 15-17 \text { age group took } \\
\text { place predominantly at parties and } \\
\text { friends' houses, as well as at family } \\
\text { gatherings } \\
\text { Only a small number of survey } \\
\text { respondents raised negative } \\
\text { consequences of consuming AEDs }\end{array}$ \\
\hline $\begin{array}{l}\text { O'Dea } \\
(2003)^{71}\end{array}$ & $\begin{array}{l}\text { Full } \\
\text { paper }\end{array}$ & Strong & Australia & $\begin{array}{l}\text { Boys and girls } \\
(n=78) 11- \\
18 \text { years }\end{array}$ & Focus groups & $\begin{array}{l}\text { To explore the type of } \\
\text { nutritional supplements and } \\
\text { drinks consumed by } \\
\text { adolescents, along with } \\
\text { reasons for consumption }\end{array}$ & $\begin{array}{l}\text { In the } 2 \text { weeks prior to the focus groups, } \\
42.3 \% \text { of participants had consumed } \\
\text { EDs (compared with } 54.6 \% \text { who } \\
\text { consumed sports drinks) } \\
\text { Reasons for consumption of EDs: } \\
\text { energy, taste, sports performance, soft } \\
\text { drink substitute, peer group pressure, } \\
\text { attractive packaging }\end{array}$ \\
\hline
\end{tabular}


that energy drink use was correlated with hours spent watching TV or playing video games, and Azagba et $a t^{48}$ and Nowak and Jasionowski, ${ }^{43}$ who found that consumption was more likely among young people who participated in sports, suggesting a link with diverse leisure activities.

\section{Detrimental health and other effects}

Using a representative sample of Finns aged 12-18 years, Huhtinen $e t a l^{31}$ found that daily use of energy drinks was strongly associated with four health symptoms: headache, sleeping problems, irritation and tiredness/fatigue. Those who used energy drinks several times a day were 4.5 times as likely to experience headaches and 3.5 times as likely to experience sleeping problems, in comparison with those who did not consume these drinks. However, a more recent study found that the relationship between energy drinks and health symptoms was partly mediated through going to bed late. ${ }^{63}$ A similar survey of 10-12 years in Iceland found that prevalence of physical symptoms such as headaches, stomach aches and sleeping problems generally increased with greater energy drink use for boys and girls, although the frequency of these symptoms was less common among boys on all occasions $(\mathrm{p}<0.001) .{ }^{42}$ Other cross-sectional studies have demonstrated positive correlations between energy drink consumption and sleeping problems, ${ }^{46}{ }^{61}$ self-reported medical treatment for an injury, ${ }^{57}$ odds of sustaining a recent or lifetime traumatic brain injury ${ }^{41}$ and hyperactivity/inattention symptoms. ${ }^{45}$

The link between adverse health outcomes and ingestion of energy drinks is supported by routinely collected poison centre data from Australia and the USA. ${ }^{64-66}$ However, these are based on self-report data and the numbers are relatively small. For example, 62 children (mean age 36 months) who had accidentally ingested energy drinks were reported to the New South Wales Poisons Information Centre between 2004 and 2010. ${ }^{65}$ Fourteen had symptoms probably related to energy drink consumption-most commonly hyperactivity-and nine required assessment in hospital. In the USA, 4854 calls $(0.2 \%)$ received by the National Poison Data System in 2010-2011 were for energy drink exposure cases. ${ }^{64}$ Almost half $(46 \%)$ were under 6 years, but older children reported the largest proportion of moderate or major effects, such as cardiac rhythm disturbances, hypertension and hyperthermia.

\section{Impact on sports performance}

Of the three experimental studies identified through the review, two measured the effects of a commercially available energy drink on aspects of sports performance in junior athletes. Pre-exercise ingestion of an energy drink significantly improved handgrip force, running pace at high intensity and number of sprints during a simulated match among tennis players, ${ }^{67}$ and enhanced jump performance, mean leg muscle power output, perception of muscle power and perceived endurance among basketball players. ${ }^{68}$ However, it did not have any influence on mean running pace, peak running speed or ball velocity in the first study, or the precision of basketball shots, number of free throws per second or distances covered by the players in the second study. During the simulated tennis match, sweat rate was slightly higher in the experimental group, producing significantly higher dehydration $(\mathrm{p}<0.05) .{ }^{67}$

\section{Attitudes towards energy drink consumption}

Three major themes emerged through our analysis of the qualitative or mixed method studies and relevant survey results: reasons for use; influences on use and perceived efficacy and impact.

\section{Reasons for use}

Taste was consistently reported as the primary driver motivating the purchase and consumption of energy drinks, with energy-seeking emerging as an important but secondary driver. ${ }^{69-72}$ Participants involved in sports, particularly boys, reported using energy drinks as stimulants to enhance their sports performance. Others described using energy drinks as an alternative to soft drinks but only when they had enough money, as they were reported to be more expensive. Typical responses included: "Wakes you up, makes you feel alert and it tastes nice"; "It makes me go hyper" and "I drink it before soccer and I don't lose energy as fast". ${ }^{72}$ Jones $^{71}$ explored perceptions of alcohol-energy drinks (AEDs) among 12-17 years and suggested that young people liked them because they increased the 'fun' at parties and acted as a 'pick me up'. They also found that the packaging of AEDs (to look like soft drinks) was a factor, particularly for younger teenagers and girls.

\section{Influences on use}

Advertising and brand loyalty emerged as major influences on young people's use of energy drinks, with participants reporting seeing them advertised on TV, the internet, through games promotions, via sports sponsorship and in shops. In a focus group study involving three age groups (16-21, 22-28 and 29-35 years), industry marketing was seen to target specific drinks at men or women, using sexualised imagery and humour. ${ }^{69}$ Participants in the youngest age group appeared to be more conscious than those in the older groups of the social image they were portraying in their choices, as well as being more sensitive to peer influences when making purchasing decisions. Social situations-and spending time with friends-provided a common context for energy drink consumption across the studies. Parents also played a key role in influencing participants' use of energy drinks, either by disapproving and prohibiting or encouraging and endorsing their use. ${ }^{70} \mathrm{It}$ was generally agreed that energy drinks were easily accessible, from convenience stores or supermarkets, provided by parents, shared by siblings or friends, or obtained free at sponsored events. 


\section{Perceived efficacy and impact}

Energy drinks were perceived to confer various beneficial effects on young people's bodies and their sports performance. Participants in one study described shortterm health benefits, prevention of illness, improved immunity and a desire to rectify a poor diet. ${ }^{72}$ Others described scenarios where adults used energy drinks to effectively alleviate tiredness related to work, travel or family commitments, leading Costa $e t a l^{70}$ to suggest that these drinks were "normalised and perceived as necessary to meet the demands of a busy lifestyle' (p. 187). Few participants across the studies raised any negative or harmful effects, suggesting young people were either unaware of, or chose to ignore, the possible risks. Negative consequences associated with using AEDs were perceived to relate to the inclusion of a stimulant and depressant in one drink, and difficulties sleeping after consumption. ${ }^{71}$ In the study by Bunting et $a l^{69}$ more negative connotations became apparent in the older, adult age groups (22-28 and 29-35 years), who displayed greater scepticism as to whether energy drinks were safe. However, concerns regarding sugar content emerged across all groups and moderation was stressed due to the perceived risks of overconsumption, as opposed to general consumption of energy drinks. The youngest age group (16-21 years) believed these drinks were safe as they would not be on sale if caffeine levels were too high. Findings from other studies highlight limited knowledge of the ingredients of energy drinks, particularly among younger participants. ${ }^{70} 71$

\section{DISCUSSION}

\section{Summary of principal findings}

This review set out to examine evidence of any associations between children and young people's health and well-being, social, behavioural and educational outcomes, and their consumption of energy drinks. It also sought to explore consumer experiences and attitudes towards these drinks.

The evidence demonstrates that the use of energy drinks by children and young people is associated with a number of adverse outcomes and health-damaging behaviours. A total of 410 studies were located, with 46 meeting our inclusion criteria. Two randomised controlled trials demonstrated that pre-exercise ingestion of an energy drink had a positive impact on some aspects of sports performance. However, both studies involved small numbers of elite junior athletes and the results should therefore be treated with some caution. Several cross-sectional studies indicated that energy drink use by children and young people was strongly and positively associated with higher rates of smoking, alcohol and other substance use, as well as being linked to physical health symptoms such as headaches, stomach aches, hyperactivity and insomnia. Two studies provided some evidence of a dose-response effect, although none of the studies was able to determine causality. Use was found to be patterned by gender, with boys consuming more energy drinks than girls, and also by age, although there was some disagreement between studies on the direction of the association. Interestingly, the highest consumption levels have been observed in sedentary individuals and in physically active individuals, suggesting a link with sport as well as screen-based leisure activities. Previous qualitative studies have reported perceived beneficial effects on young people's bodies and sports performance, with little mention of any negative effects and limited knowledge of energy drink ingredients among participants. Taste and energy-seeking were identified as key drivers for consumption. Advertising and brand loyalty have been highlighted as major influences on young people's attitudes towards energy drinks, and peers, parents and siblings were also found to play an important role.

\section{Comparison with other studies}

This is the first comprehensive review of the scientific literature to focus exclusively on evidence relating to the consumption of energy drinks by children and young people. Previous reviews have tended to examine the benefits and risks associated with specific energy drink components, such as sugar or caffeine. These studies provide important insights but fail to account for the fact that the presence of other substances such as guarana, ginseng and taurine in variable quantities may generate uncertain interactions and exacerbate any risks. ${ }^{73}$ In addition, there is an established biochemical interaction between energy drink contents and alcohol, resulting in physical and psychological side effects and increased risk-taking behaviour. ${ }^{74} 75$ The aforementioned EFSA study found that more than half of young energy drink consumers (53\%) reported co-consumption with alcohol. ${ }^{3}$ Qualitative studies suggest that young adults use energy drinks to continue partying and drinking alcohol over a longer period, and that they may experience negative effects ranging from difficulty sleeping to being admitted to hospital. ${ }^{76}$ Further evidence is provided by the numerous clinical case reports relating to young people receiving emergency treatment for overconsumption of energy drinks with or without alcohol in recent years (for examples, see: ${ }^{78-82}$ ).

Consumption of sugar-sweetened beverages by children and young people has been shown to result in greater weight gain, increased body mass index and higher incidence of type 2 diabetes. ${ }^{18} 83$ A review on the suitability of caffeinated drinks for children found that high caffeine intakes $(>5 \mathrm{mg} / \mathrm{kg}$ body weight per day) were associated with an increased risk of anxiety and withdrawal symptoms. ${ }^{84}$ However, evidence from adult studies and expert panels was used to suggest that relatively small amounts of caffeine may benefit cognitive function and sports performance, as well as contributing to daily fluid intakes. Furthermore, the author was a paid member of the Tea Advisory Panel and the work was funded by the UK Tea Council. Several other studies 
located through our review were funded by the soft drinks industry or conducted by researchers with acknowledged conflicts of interest. Previous independent reviews on energy drinks highlight a number of implications for children's health and well-being, although they also draw on expert opinion and adult studies. $^{12}{ }^{13}$ 24-27 A report by the Committee on Nutrition and the Council on Sports Medicine and Fitness in the US raises concerns about the unintentional (through the use of energy drinks for rehydration) and intentional (through the use of energy drinks to combat fatigue) ingestion of potentially large amounts of caffeine and other stimulant substances. ${ }^{12}$ They suggest that paediatricians have a role to play in educating children and parents on the differences between sports and energy drinks, and to counsel that routine ingestion of sugar-sweetened beverages should be avoided or restricted.

\section{Strengths and limitations of the study}

The strengths of our review include the comprehensiveness of our searches, the systematic study selection process and rigorous synthesis methods used. The review was undertaken by a multidisciplinary team of independent academic researchers. The inclusion of qualitative research exploring children and young people's views on energy drinks, alongside quantitative studies on health and other effects associated with their consumption, helps to enhance the relevance of the findings for the design and evaluation of future policy and practice interventions.

As with any literature review, the strength of our conclusions is limited by the quality of the individual studies, which varied. The small sample sizes in the experimental and retrospective studies, reliance on selfreport data in many of the observational studies and small number of qualitative studies located are all limitations of the review. Very few of the included studies examined educational or social outcomes, highlighting a need for further research that examines the short-term and long-term impact of energy drinks in relation to a wider range of outcomes. Almost half of the studies were conducted in North America and most involved high school students rather than younger children. Owing to time and resource constraints, we excluded non-English language publications and may not have identified all unpublished studies.

\section{Conclusion and policy implications}

This review adds to the growing evidence base on the health effects associated with energy drink consumption and suggests that there may be more negative than positive implications for children and young people. However, factors such as taste, brand loyalty and perceived beneficial effects help to enhance their popularity among young consumers. Consideration of the patterns and reasons for energy drink consumption identified in this review may help future interventions to ensure appropriate behaviours are targeted and are relevant to the population. Gender was identified as an important factor, in combination with gendered marketing and perceived links to sports performance, particularly among boys. The challenge for policies and interventions that seek to address this issue is to recognise the complexities of children and young people's consumption choices. Although health education targeting individuals is unlikely to achieve a substantial impact, definitive information about the safety of energy drink consumption should be provided by healthcare and other professionals, who may in turn need guidance, for example, from the UK National Institute of Health and Care Excellence (NICE). More research is needed to explore the longer-term health impacts, given that childhood and adolescence are critical yet understudied periods in the development of health-related behaviours. The potential effects of heavy and long-term energy drink consumption on child development, behaviour and educational outcomes also warrant further study.

\section{Author affiliations}

${ }^{1}$ School of Medicine, Pharmacy and Health, Durham University Queen's Campus, Stockton-on-Tees, UK

${ }^{2}$ Fuse (UKCRC Centre for Translational Research in Public Health), Newcastle University, Newcastle-upon-Tyne, UK

${ }^{3}$ School of Health and Social Care, Teesside University, Middlesbrough, UK

${ }^{4}$ Department of Psychology, Durham University, Durham, UK

Contributors SV, AAL, MC and DMR designed the study and obtained funding. SV wrote the review protocol and conducted the searches. SV, DMR, $M C$ and AAL screened titles and full papers, assessed study quality, extracted data and undertook the narrative synthesis. SJC provided administrative and technical support. All authors contributed to the drafting of the paper and approved the final submitted version. The authors of this manuscript take responsibility for the integrity of the data and the accuracy of the data analysis.

Funding The review was funded as part of a larger study by The Children's Foundation (registered charity no. 1000013). AAL and MC are members of Fuse (UKCRC Centre for Translational Research in Public Health), and SV is an associate member. Funding for Fuse comes from the British Heart Foundation, Cancer Research UK, Economic and Social Research Council, Medical Research Council, and the National Institute for Health Research, under the auspices of the UK Clinical Research Collaboration, and is gratefully acknowledged (MRC grant number MR/K02325X/1).

Disclaimer This paper reports independent research commissioned and funded by The Children's Foundation Child Health Research Programme 2013-2014. The funders had no role in the study design, data collection and analysis, or preparation of any publications or dissemination materials. The views expressed in this publication are those of the authors and not necessarily those of The Children's Foundation or any other funder.

Competing interests None declared.

Provenance and peer review Not commissioned; externally peer reviewed.

Data sharing statement No additional data are available.

Open Access This is an Open Access article distributed in accordance with the terms of the Creative Commons Attribution (CC BY 4.0) license, which permits others to distribute, remix, adapt and build upon this work, for commercial use, provided the original work is properly cited. See: http:// creativecommons.org/licenses/by/4.0/ 


\section{REFERENCES}

1. BSDA. Code of practice on energy drinks. London: British Soft Drinks Association, 2015.

2. BDSA. Changing Tastes. The UK Soft Drinks Annual Report 2015. London: British Soft Drinks Association, 2015.

3. Nomisma-Arete Consortium. External scientific report. Gathering consumption data on specific consumer groups of energy drinks. Parma, Italy: European Food Safety Authority, 2013.

4. Alford $\mathrm{C}$, Cox $\mathrm{H}$, Wescott $\mathrm{R}$. The effects of red bull energy drink on human performance and mood. Amino Acids 2001;21: 139-50.

5. Ganio MS, Klau JF, Casa DJ. Effect of caffeine on sport-specific endurance performance: a systematic review. J Strength Cond Res 2009;23:315-24.

6. Peeling P, Dawson B. Influence of caffeine ingestion on perceived mood states, concentration, and arousal levels during a 75-min university lecture. Adv Physiol Educ 2007;31:332-5.

7. Scholey AB, Kennedy DO. Cognitive and physiological effects of an 'energy drink': an evaluation of the whole drink and of glucose, caffeine and herbal flavouring fractions. Psychopharmacology (Berl) 2004;176:320-30

8. Ishak WW, Ugochukwu C, Bagot $\mathrm{K}$, et al. Energy drinks: psychological effects and impact on well-being and quality of life-a literature review. Innov Clin Neurosci 2012;9:25-34

9. Oddy $\mathrm{WH}, \mathrm{O}$ 'Sullivan TA. Energy drinks for children and adolescents. BMJ 2009;339:b5268.

10. Smithers R. Call for ban on selling 'addictive' energy drinks to children. The Guardian 26 February 2015

11. Tibbetts $\mathrm{G}$. Teenager collapsed after becoming addicted to Red Bull. The Telegraph 21 November 2008.

12. Committee on Nutrition and the Council on Sports Medicine and Fitness. Sports drinks and energy drinks for children and adolescents: are they appropriate? Pediatrics 2011;127:1182-9.

13. Seifert SM, Schaechter JL, Hershorin ER, et al. Health effects of energy drinks on children, adolescents, and young adults. Pediatrics 2011;127:511-28.

14. Terry-McElrath YM, O'Malley PM, Johnston LD. Energy drinks, soft drinks, and substance use among United States secondary school students. J Addict Med 2014;8:6-13.

15. Harris R, Nicoll AD, Adair PM, et al. Risk factors for dental caries in young children: a systematic review of the literature. Community Dent Health 2004;21(1 Suppl):71-85.

16. Ludwig D, Peterson K, Gortmaker S. Relation between consumption of sugar-sweetened drinks and childhood obesity: a prospective, observational analysis. Lancet 2001;357:505-8.

17. Mrdjenovic G, Levitsky DA. Nutritional and energetic consequences of sweetened drink consumption in 6- to 13-year-old children. $J$ Pediatr 2003;142:604-10.

18. Scientific Advisory Committee on Nutrition. Carbohydrates and health. London: TSO, 2015.

19. Civil Service. What is a Rapid Evidence Assessment? http://www. civilservice.gov.uk/networks/gsr/resources-and-guidance/ rapid-evidence-assessment/what-is (accessed 13 Jun 2014).

20. Watt A, Cameron A, Sturm L, et al. Rapid versus full systematic reviews: validity in clinical practice? ANZ J Surg 2008;78:1037-40.

21. Parkill AF, Clavisi R, Pattuwage $L$, et al. Searches for evidence mapping: effective, shorter, cheaper. J Med Libr Assoc 2011;99:157-60

22. CASP. CASP Checklists. 2014. http://www.casp-uk.net/\# casp-tools-checklists/c18f8 (accessed 16 Jun 2014).

23. Effective Public Health Practice Project. Quality assessment tool for quantitative studies. Ontario, Canada: Public Health Research, Education and Development Program (PHRED), 2009.

24. Alsunni AA. Energy drink consumption: beneficial and adverse health effects. Int J Health Sci (Qassim) 2015;9:468-47.

25. Breda JJ, Whiting SH, Encarnação R, et al. Energy drink consumption in Europe: a review of the risks, adverse health effects and policy options to respond. Front Public Health 2014;2:134.

26. Ibrahim NK, Iftikhar R. Energy drinks: Getting wings but at what health cost? Pak J Med Sci 2014;30:1415-19.

27. Owens JA, Mindell J, Baylor A. Effect of energy drink and caffeinated beverage consumption on sleep, mood, and performance in children and adolescents. Nutr Rev 2014;72:65-71.

28. Popay J, Roberts H, Sowden A, et al. Guidance on the Conduct of Narrative Synthesis in Systematic Reviews. A Product from the ESRC Methods Programme. Swindon: Economic and Social Research Council (ESRC), 2006.

29. Azagba S, Langille D, Asbridge M. An emerging adolescent health risk: caffeinated energy drink consumption patterns among high school students. Prev Med 2014;62:54-9.
30. Gambon DL, Brand HS, Boutkabout C, et al. Patterns in consumption of potentially erosive beverages among adolescent school children in the Netherlands. Int Dent $J$ 2011;61:247-51.

31. Huhtinen $\mathrm{H}$, Lindfors $\mathrm{P}$, Rimpelä A. Adolescents' use of energy drinks and caffeine induced health complaints in Finland. Eur J Public Health 2013;23(Suppl 1):166.

32. Kumar GS, Park S, Onufrak S. Association between reported screening and counseling about energy drinks and energy drink intake among U.S. adolescents. Patient Educ Couns 2014;94:250-4.

33. Larson N, DeWolfe J, Story M, et al. Adolescent consumption of sports and energy drinks: linkages to higher physical activity, unhealthy beverage patterns, cigarette smoking, and screen media use. J Nutr Educ Behav 2014;46:181-7.

34. Locatelli D, Sanchez Z, Opaleye E, et al. Socioeconomic influences on alcohol use patterns among private school students in São Paulo. Rev Bras Psiquiatr 2012;34:193-200.

35. Musaiger O, Zagzoog N. Knowledge, attitudes and practices toward energy damong adolescents in Saudi Arabia. Glob J Health Sci 2014;6:42-6.

36. Bryant Ludden A, Wolfson AR. Understanding adolescent caffeine use: connecting use patterns with expectancies, reasons, and sleep. Health Educ Behav 2010;37:330-42.

37. Temple JL, Dewey AM, Briatico LN. Effects of acute caffeine administration on adolescents. Exp Clin Psychopharmacol 2010;18:510-20.

38. Emond JA, Gilbert-Diamond D, Tanski SE, et al. Energy drink consumption and the risk of alcohol use disorder among a national sample of adolescents and young adults. J Pediatr 2014;165:1194-200.

39. Evren C, Evren B. Energy-drink consumption and its relationship with substance use and sensation seeking among 10th grade students in Istanbul. Asian J Psychiatr 2015;15:44-50.

40. Gallimberti L, Buja A, Chindamo S, et al. Prevalence of substance use and abuse in late childhood and early adolescence: what are the implications? Prev Med Rep 2015;2:862-7.

41. Ilie G, Boak A, Mann RE, et al. Energy drinks, alcohol, sports and traumatic brain injuries among adolescents. PLOS ONE 2015;10: e0135860

42. Kristjansson AL, Sigfusdottir ID, Mann MJ, et al. Caffeinated sugar-sweetened beverages and common physical complaints in Icelandic children aged 10-12 years. Prev Med 2014;58:40-4.

43. Nowak D, Jasionowski A. Analysis of the consumption of caffeinated energy drinks among Polish adolescents. Int J Environ Res Public Health 2015;12:7910-21.

44. Reid JL, Hammond D, McCrory C, et al. Use of caffeinated energy drinks among secondary school students in Ontario: prevalence and correlates of using energy drinks and mixing with alcohol. Can J Public Health 2015;106:e101-8.

45. Schwartz DL, Gilstad-Hayden K, Carroll-Scott A, et al. Energy drinks and youth self-reported hyperactivity/inattention symptoms. Acad Pediatr 2015;15:297-304.

46. Richards G, Smith AP. Breakfast and energy drink consumption in secondary school children: breakfast omission, in isolation or in combination with frequent energy drink use, is associated with stress, anxiety, and depression cross-sectionally, but not at 6-month follow-up. Front Psychol 2016;7:106.

47. Gallimberti L, Buja A, Chindamo S, et al. Energy drink consumption in children and early adolescents. Eur J Pediatr 2013;172:1335-40.

48. Azagba S, Langille D, Asbridge M. The consumption of alcohol mixed with energy drinks: prevalence and key correlates among Canadian high school students. CMAJ Open 2013;1:E19-26.

49. Faris MeAl, Epuru S, Al-Shimmari S, et al. Alarming high levels of energy drinks consumption among school children in Hail, northern of Saudi Arabia. Int J Child Health Nutr 2015;4:1-13.

50. Magnezi R, Bergman LC, Grinvald-Fogel H, et al. A survey of energy drink and alcohol mixed with energy drink consumption. Isr J Health Policy Res 2015;4:55

51. Arria AM, Bugbee BA, Caldeira KM, et al. Evidence and knowledge gaps for the association between energy drink use and high-risk behaviors among adolescents and young adults. Nutr Rev 2014;72 (Suppl 1):87-97.

52. Park S, Blanck HM, Sherry B, et al. Factors associated with sugar-sweetened beverage intake among United States high school students. J Nutr 2012;142:306-12.

53. Miyake ER, Marmorstein NR. Energy drink consumption and later alcohol use among early adolescents. Addict Behav 2015;43:60-5.

54. Vilija M, Romualdas M. Unhealthy food in relation to posttraumatic stress symptoms among adolescents. Appetite 2014;74:86-91. 
55. Azagba S, Sharaf MF. Is alcohol mixed with energy drinks consumption associated with susceptibility to smoking? Prev Med 2014;61:26-8.

56. Cotter BV, Jackson DA, Merchant RC, et al. Energy drink and other substance use among adolescent and young adult emergency department patients. Pediatr Emerg Care 2013;29:1091-7.

57. Hamilton HA, Boak A, Ilie G, et al. Energy drink consumption and associations with demographic characteristics, drug use and injury among adolescents. Can J Public Health 2013;104: e496-501.

58. Choi HJ, Wolford-Clevenger C, Brem MJ, et al. The temporal association between energy drink and alcohol use among adolescents: a short communication. Drug Alcohol Depend 2016;158:164-6.

59. Lubman DI, Droste N, Pennay A, et al. High rates of alcohol consumption and related harm at schoolies week: a portal study. Aust N Z J Public Health 2014;38:536-41.

60. Martz ME, Patrick ME, Schulenberg JE. Alcohol mixed energy drink use among US. 12th-grade students: prevalence, correlates, and associations with unsafe driving. J Adolesc Health 2015;56: 557-63.

61. Van Batenburg-Eddes T, Lee NC, Weeda WD, et al. The potential adverse effect of energy drinks on executive functions in early adolescence. Front Psychol 2014;5:457.

62. Al-Hazzaa HM, Al-Sobayel HI, Abahussain NA, et al. Association of dietary habits with levels of physical activity and screen time among adolescents living in Saudi Arabia. J Hum Nutr Diet 2014;27(Suppl 2):204-13.

63. Koivusilta L, Kuoppamäki H, Rimpelä A. Energy drink consumption, health complaints and late bedtime among young adolescents. Int J Public Health 2016;61:299-306.

64. Seifert SM, Seifert SA, Schaechter JL, et al. An analysis of energy-drink toxicity in The National Poison Data System. Clin Toxicol (Phila) 2013;51:566-74.

65. Gunja N, Brown JA. Energy drinks: health risks and toxicity. Med $J$ Aust 2012;196:46-9.

66. Hernandez RA, Villarreal CL, Fernandez MC. Poison center data identifies increase in energy drink consumption and teens as highest at-risk group. Clin Toxicol 2009;47:756.

67. Gallo-Salazar C, Areces F, Abián-Vicén J, et al. Enhancing physical performance in elite junior tennis players with a caffeinated energy drink. Int J Sports Physiol Perform 2015;10:305-10.

68. Abian-Vicen J, Puente C, Salinero JJ, et al. A caffeinated energy drink improves jump performance in adolescent basketball players. Amino Acids 2014:46:1333-41.

69. Bunting H, Baggett A, Grigor J. Adolescent and young adult perceptions of caffeinated energy drinks. A qualitative approach. Appetite 2013;65:132-8.
70. Costa BM, Hayley A, Miller P. Young adolescents' perceptions, patterns, and contexts of energy drink use. A focus group study. Appetite 2014;80:183-9.

71. Jones SC. 'You wouldn't know it had alcohol in it until you read the can': adolescents and alcohol-energy drinks. Australas Market $J$ 2011;19:189-95. 005

72. O'Dea JA. Consumption of nutritional supplements among adolescents: usage and perceived benefits. Health Educ Res 2003;18:98-107.

73. Sanchis-Gomar F, Pareja-Galeano H, Cervellin G, et al. Energy drink overconsumption in adolescents: implications for arrhythmias and other cardiovascular events. Can J Cardiol 2015;31:572-5.

74. Patrick ME, Maggs JL. Energy drinks and alcohol: links to alcohol behaviors and consequences across 56 days. $J$ Adolesc Health 2013:54:454-9.

75. Peacock A, Bruno R, Martin FH. The subjective physiological, psychological, and behavioural risk-taking consequences of alcohol and energy drink co-ingestion. Alcohol Clin Exp Res 2012;36:2008-15.

76. Jones S, Barrie L, Berry N. Why (not) alcohol energy drinks? A qualitative study with Australian university students. Drug Alcohol Rev 2012;31:281-7.

77. Pennay A, Lubman D. Alcohol and energy drinks: a pilot study exploring patterns of consumption, social contexts, benefits and harms. BMC Res Notes 2012;5:369.

78. Di Rocco JR, During A, Morelli PJ, et al. Atrial fibrillation in healthy adolescents after highly caffeinated beverage consumption: two case reports. J Med Case Rep 2011;5:18.

79. Dufendach KA, Horner JM, Cannon BC, et al. Congenital type 1 long QT syndrome unmasked by a highly caffeinated energy drink. Heart Rhythm 2012;9:285-8.

80. Schöffl I, Kothmann JF, Schöffl V, et al. 'Vodka energy': too much for the adolescent nephron? Pediatrics 2011;128:e227-31.

81. Terlizzi R, Rocchi C, Serra M, et al. Reversible postural tachycardia syndrome due to inadvertent overuse of Red Bull. Clin Auton Res 2008;18:221-3.

82. Yazdi AS, Mayser P, Sander CA. Lichen aureus with clonal T cells in a child possibly induced by regular consumption of an energy drink. $J$ Cutan Pathol 2008;35:960-2.

83. Imamura F, O'Connor L, Ye Z, et al. Consumption of sugar sweetened beverages, artificially sweetened beverages, and fruit juice and incidence of type 2 diabetes: systematic review, meta-analysis, and estimation of population attributable fraction. BMJ 2015;351:h3576.

84. Ruxton $\mathrm{C}$. The suitability of caffeinated drinks for children: a systematic review of randomised controlled trials, observationa studies and expert panel guidelines. J Hum Nutr Diet 2013;27:342-57. 